\title{
Abnormal hemoglobin genotypes and $A B O$ and rhesus blood groups associated with HIV infection among HIV-exposed infants in North Western Nigeria
}

\author{
This article was published in the following Dove Press journal: \\ Pathology and Laboratory Medicine International \\ 23 June 2014 \\ Number of times this article has been viewed
}

\section{Fiekumo I Buseri \\ Charity N Okonkwo ${ }^{2}$}

'Hematology and Blood Transfusion Science Unit, Department of Medical Laboratory Science, Niger Delta University, Wilberforce Island, Bayelsa State, Nigeria; ${ }^{2}$ Department of Medical Laboratory Sciences, Rivers State University of Science and Technology, Port Harcourt, Nigeria
Correspondence: Fiekumo I Buseri Department of Medical Laboratory Sciences, Faculty of Basic Medical Sciences, College of Health Sciences, Niger Delta University, Wilberforce Island, Bayelsa State, Nigeria Tel +234803 3705675

Email fibuseri@yahoo.com
Background: Hemoglobin genotypes and blood groups have been known to be associated with diseases, but the relationship with human immunodeficiency virus (HIV) infection among Nigerian infants is not well known.

Objective: This study aims to determine the association between hemoglobin genotypes and blood groups with HIV infection among HIV-exposed Nigerian infants.

Methods: This cross-sectional study examined 312 HIV-exposed infants (aged 8-16 months) in Sokoto State, Nigeria. HIV screening was performed using the HIV DNA polymerase chain reaction technique on dried blood spots. Hemoglobin electrophoresis and ABO and Rhesus (Rh) blood groups were carried out using standard techniques.

Results: This study found $20.5 \%$ HIV-1 seropositivity among the infants, with $20.9 \%$ of males and $20.1 \%$ of females positive for HIV-1. Babies' sex and HIV seropositivity was not significant $\left(\chi^{2}=0.27, d f=1, P=0.869\right)$. The blood group distribution was $\mathrm{O}(43.3 \%), \mathrm{A}(36.8 \%), \mathrm{B}(15.7 \%)$, $\mathrm{AB}(4.2 \%), \mathrm{RhD}^{+}(95.6 \%)$, and $\mathrm{RhD}^{-}(4.4 \%)$. The combined $\mathrm{ABO}$ and $\mathrm{Rh}$ blood groups among the study population were $\mathrm{O}^{+}(40.1 \%), \mathrm{A}^{+}(36.2 \%), \mathrm{B}^{+}(15.1 \%), \mathrm{AB}^{+}(4.2 \%), \mathrm{O}^{-}(3.2 \%)$, $\mathrm{A}^{-}(0.6 \%)$, and $\mathrm{B}^{-}(0.6 \%)$. No $\mathrm{AB}^{-}$baby was found. The association between blood groups and HIV seropositivity was not significant (Fisher's exact test $=9.140 ; P=0.169$ ); however, group $\mathrm{AB}^{+}$showed the highest probable association with HIV seropositivity $(46.2 \%)$, followed by $\mathrm{A}^{+}$ (23.9\%). The prevalence of hemoglobin genotypes was AA (71.5\%), AS (25.3\%), AC (2.2\%), and SC (1.0\%). Hemoglobin SS and other hemoglobin variants were not found. A significant association $\left(\chi^{2}=8.432, d f=3, P=0.034\right)$ was observed between SC and HIV-1 infection, but not with $\mathrm{ABO}$ and $\mathrm{Rh}$ blood groups.

Conclusion: Hemoglobin variant SC showed a significant association with HIV-1 infection, but not with $\mathrm{ABO}$ and $\mathrm{Rh}$ blood groups. Further studies are recommended to confirm this finding.

Keywords: hemoglobin, blood groups, HIV, infants, Nigeria

\section{Introduction}

Hemoglobin is the intracellular protein in erythrocytes, consisting of four polypeptide globin chains, each of which is folded around a heme molecule. It is responsible for the transport of oxygen from the lungs to the tissues and carbon dioxide from the tissues to the lungs. The globin chains are encoded by their respective genes located on chromosome 11 and chromosome 16 and are both known to have several alleles. ${ }^{1}$ Many of these alleles suffer point mutations in the DNA sequence that lead to single amino acid substitutions in the globin moiety, resulting in the production of hemoglobin variants. The abnormal hemoglobin genotype occurs when an affected individual 
inherits mutated globin gene(s) such as hemoglobin S, C, D, and $\mathrm{E}$ from both parents. Abnormal hemoglobin genotypes are inherited in an autosomal codominant fashion and occur by different combinations.

Several hundred abnormal hemoglobin genotypes have been discovered; however, only a few are common and cause major public health problems in many parts of the world. ${ }^{1}$ According to the World Health Organization, Nigeria ranks first as the sickle cell endemic country in the world with an annual infant death of 100,000 - representing $8 \%$ of infant mortality in the country. ${ }^{2}$ The World Health Organization also reported that an average of 150,000 infants are born with sickle cell disease in Nigeria. ${ }^{2}$ The most commonly encountered abnormal hemoglobin genotypes among Nigerians include AS, AC, SC, and SS.

It has been reported that abnormal hemoglobin genotypes have been associated with a wide range of moderate to severe hemolytic anemia, leading to a high degree of morbidity and mortality among affected individuals as well as susceptibility to renal medullary carcinoma and hyposthenuria. ${ }^{3,4}$

Blood groups are types of inherited antigenic substances on the surface of red blood cells, other cell types, and body secretions that are coded by alleles at different loci on a chromosome. ${ }^{5}$ Several of these red blood cell surface antigens that stem from one allele (or very closely linked genes) collectively form a blood group system. A total of 30 human blood group systems are now recognized by the International Society of Blood Transfusion. ${ }^{6}$ Of these, the ABO and Rhesus (Rh) blood group systems, which were the first and fourth to be discovered, respectively, are the most frequently studied genetic markers in humans. ${ }^{7,8}$ Apart from their importance in blood transfusion practice, they are useful in genetic studies of populations and also resolving medicolegal issues like disputed parentage. ${ }^{7}$

In addition, many studies have associated blood group systems with different disease conditions in different parts of the world. For example, several research works have shown that stomach cancer has a higher prevalence rate among blood group A than the rest of the ABO blood groups. ${ }^{3,9}$ Blood group $\mathrm{O}$ individuals have also been reported by several workers $^{5,10}$ to be more prone to peptic ulcer disease due to lack of N-acetyl-glucosamine necessary for the development of mucosa lining of their alimentary canal. A study in Nigeria has reported blood group AB to be associated with human immunodeficiency virus 2 (HIV-2) infection. ${ }^{11}$

Although hemoglobin genotypes and blood groups have been known to be associated with diseases, the association between hemoglobin genotypes and blood groups with HIV infection among HIV-exposed Nigerian infants is not well known. This study was therefore designed to investigate the association between abnormal hemoglobin genotypes and $\mathrm{ABO}$ and Rh blood groups with HIV infection among HIV-exposed infants in North Western Nigeria.

\section{Materials and methods Study design}

This cross-sectional study was conducted among 312 HIV-exposed infants from newly diagnosed HIV-positive mothers among antenatal attendees between March 2012 and February 2013.

\section{Setting}

This study was conducted at four different hospital settings in Sokoto State, Nigeria. These were: 1) Usmanu Danfodiyo University Teaching Hospital - a tertiary health care institution located in Sokoto; 2) Specialist Hospital Sokoto - a secondary health care institution located in Sokoto; 3) Dogon-Daji General Hospital - a primary health center located in the Dogon-Daji local government area of Sokoto State; and 4) Holy Family Health Center - another primary health center located in the Wamako local government area of Sokoto State. These four hospitals were chosen because they offer free prevention of mother-to-child transmission of HIV services.

\section{Informed consent and ethical clearance}

Ethical clearance was obtained from the management of the hospitals and informed consent was obtained from each mother of the infant who participated in the study.

\section{Sample collection and analyses}

Blood (1 mL) was collected from each infant into an ethylenediaminetetraacetic acid microcontainer and properly mixed for the determination of the baby's hemoglobin genotype, $\mathrm{ABO}$ and $\mathrm{Rh}$ blood groups, and HIV diagnosis.

\section{Determination of $A B O$ and Rh phenotypes}

Red cell phenotyping was carried out manually with standard tube technique. For ABO blood grouping, a drop of anti-A, anti-B, and anti-AB (Biotec Laboratories Ltd, Ipswich, UK) was added into clean test tubes labeled 1, 2, and 3, respectively, containing a drop of the baby's blood. The contents were tapped gently to mix and centrifuged for 30 seconds at $1,000 \mathrm{~g}$. The cell buttons were gently resuspended and observed for agglutination. Presence of 
agglutination constituted positive results, whereas absence of agglutination constituted negative results.

For the RhD typing, a drop of anti-D serum (Biotec) was placed in a clean, labeled test tube and a drop of control placed in a second tube. One drop of the baby's blood was then added, mixed gently, and centrifuged for 30 seconds at $1,000 \mathrm{~g}$. At the end of centrifugation, the cell buttons were gently resuspended and observed for agglutination. Agglutination was read macroscopically and microscopically in doubtful cases. All negative results were confirmed using the indirect antihuman globulin test procedure. Presence of agglutination constituted positive results, whereas absence of agglutination constituted negative results.

\section{Determination of hemoglobin electrophoresis patterns}

Hemoglobin electrophoresis was carried out using the cellulose acetate alkaline hemoglobin electrophoresis technique, which allowed for the separation of hemoglobin A, F, S, and $\mathrm{C}$ into distinct bands. Hemolysate of each sample was prepared and electrophoresed in a hemoglobin electrophoresis chamber containing Tris buffer solution for 20 minutes at $230 \mathrm{~V}$. Hemolysate from blood samples of known hemoglobin types were run as a control. The result was read by comparing the distance of migration of the test sample with known controls.

\section{Determination of infants' HIV status by HIV DNA polymerase chain reaction technique on dried blood spots}

All the HIV-exposed infants' blood samples were screened for HIV using HIV DNA polymerase chain reaction technique on dried blood spots with QIAamp ${ }^{\circledR}$ DNA Mini Kit (QIAGEN NV, Venlo, the Netherlands) following the manufacturer's instructions.

\section{Results}

A total of 312 HIV-exposed infants aged between 8-16 months (mean \pm standard deviation 11.95 \pm 2.07 months) constituted the study population. Males constituted 50.6\% (158/312), while females constituted $49.4 \%$ (154/312). The prevalence of O, A, B, AB, and Rh phenotypes is shown in Table 1 . In the ABO blood group system, $\mathrm{O}$ was the most common $(43.3 \%)$, followed by A (36.8\%), B (15.7\%), and AB (4.2\%). AB was the least prevalent blood group. In the $\mathrm{Rh}$ blood system, the majority (95.6\%) were $\mathrm{Rh}^{+}$, while $4.4 \%$ were $\mathrm{Rh}^{-}$. The combined $\mathrm{ABO}$ and $\mathrm{Rh}$ blood groups were in the order of $\mathrm{O}^{+}(40.1 \%)$,
Table I Frequency distribution of the $\mathrm{ABO}$ and Rhesus blood group phenotypes of the babies studied

\begin{tabular}{llll}
\hline $\begin{array}{l}\text { Blood } \\
\text { group }\end{array}$ & \multicolumn{2}{l}{ Rhesus blood group, $\mathbf{n}(\%)$} & Total, $\mathbf{n}(\%)$ \\
\cline { 2 - 3 } & Positive & Negative & \\
\hline A & $113(36.2 \%)$ & $2(0.6 \%)$ & $115(36.8 \%)$ \\
B & $47(15.1 \%)$ & $2(0.6 \%)$ & $49(15.7 \%)$ \\
$A B$ & $13(4.2 \%)$ & $0(0 \%)$ & $13(4.2 \%)$ \\
$O$ & $125(40.1 \%)$ & $10(3.2 \%)$ & $135(43.3 \%)$ \\
Total & $298(95.6 \%)$ & $14(4.4 \%)$ & $312(100 \%)$ \\
\hline
\end{tabular}

$\mathrm{A}^{+}(36.2 \%), \mathrm{B}^{+}(15.1 \%), \mathrm{AB}^{+}(4.2 \%), \mathrm{O}^{-}(3.2 \%), \mathrm{A}^{-}(0.6 \%)$, and $\mathrm{B}^{-}(0.6 \%)$. No $\mathrm{AB}^{-}$blood was encountered in the study population $(0 \%)$. Blood groups $\mathrm{A}^{-}$and $\mathrm{B}^{-}$had the lowest frequency $(0.6 \%$ each). The difference in the pattern of $A B O$ and $\mathrm{Rh}$ blood groups between the male and female babies was inconsequential $(P>0.05)$.

Table 2 shows a cross tabulation analysis of babies' blood groups versus HIV status and did not reveal any statistically significant difference (Fisher's exact test $=9.140 ; P=0.169$ ); however, blood group $\mathrm{AB}^{+}$showed the highest probable association with HIV seropositivity (46.2\%) followed by $\mathrm{A}^{+}(23.9 \%)$.

Table 3 shows an analysis of the babies' sex versus HIV status. Of the 158 males, 33 (20.9\%) were HIV-1 positive and $125(79.1 \%)$ were negative. Of the 154 females, 31 (20.1\%) were HIV-1 positive and 123 (79.9\%) were negative. Pearson's $\chi^{2}$ analysis revealed no statistically significant difference between the babies' sex and HIV seropositivity $\left(\chi^{2}=0.027, d f=1, P=0.869\right)$.

Table 4 summarizes the frequency distribution of the babies studied according to age groups. Nearly onethird (30.1\%) were aged $8-10$ months, $46.2 \%$ were aged $11-13$ months, and $23.7 \%$ were aged $14-16$ months.

The findings in Table 5 show that HIV seropositivity among the babies cut across all the age groups and there

Table 2 Cross tabulation analysis of babies' blood group versus HIV status

\begin{tabular}{llll}
\hline Blood group & \multicolumn{2}{l}{ HIV status, n (\%) } & Total \\
\cline { 2 - 3 } & Positive & Negative & \\
\hline $\mathrm{A}^{-}$ & 0 & $2(100 \%)$ & 2 \\
$\mathrm{~A}^{+}$ & $27(23.9 \%)$ & $86(76.1 \%)$ & 113 \\
$\mathrm{AB}^{+}$ & $6(46.2 \%)$ & $7(53.8 \%)$ & 13 \\
$\mathrm{~B}^{-}$ & 0 & $2(100 \%)$ & 2 \\
$\mathrm{~B}^{+}$ & $6(12.8 \%)$ & $41(87.2 \%)$ & 47 \\
$\mathrm{O}^{-}$ & $2(20 \%)$ & $8(80 \%)$ & 10 \\
$\mathrm{O}^{+}$ & $23(18.4 \%)$ & $102(81.6 \%)$ & 125 \\
Total & 64 & 248 & 312 \\
\hline
\end{tabular}

Notes: Fisher's exact test $=9.140 ; P=0.169$.

Abbreviation: HIV, human immunodeficiency virus. 
Table 3 Cross tabulation analysis of babies' sex versus HIV status

\begin{tabular}{llll}
\hline Sex & \multicolumn{2}{l}{ HIV status, $\mathbf{n}(\%)$} & Total \\
\cline { 2 - 3 } & Positive & Negative & \\
\hline Male & $33(20.9 \%)$ & $125(79.1 \%)$ & 158 \\
Female & $31(20.1 \%)$ & $123(79.9 \%)$ & 154 \\
Total & 64 & 248 & 312 \\
\hline
\end{tabular}

Notes: $\chi^{2}=0.027 ; \mathrm{df}=\mathrm{I} ; \mathrm{P}=0.869$.

Abbreviation: HIV, human immunodeficiency virus.

were no statistically significant differences in the proportions $\left(\chi^{2}=1.729, d f=2, P=0.440\right)$.

Table 6 shows the hemoglobin genotype frequency distribution of the HIV-exposed babies. The majority (71.5\%) were AA, followed by AS (25.3\%), AC (2.2\%), and SC (1.0\%).

Table 7 displays cross tabulation analysis of the genotype of the babies versus HIV status. The $\chi^{2}$ analysis revealed a statistically significant influence of the babies' hemoglobin genotypes on HIV seropositivity $\left(\chi^{2}=8.432, d f=3, P=0.034\right)$. The majority of infants with SC genotype $(66.7 \%)$ were reported to be HIV positive, followed by AC (42.9\%), AS $(25.3 \%)$, and AA (17.5\%).

\section{Discussion}

In this study, the hemoglobin variant SS was not found. This is in agreement with some previous authors. ${ }^{12,13}$ This may possibly suggest that the sickling gene pool is gradually reducing in this African population. It may not mean a complete absence because there are other published reports in Nigeria that carry 3.0\% SS and 2.0\% SC in South Western Nigeria. ${ }^{14}$ The zero frequency of SS in the current study population could be attributed to disturbance of the HardyWeinberg equilibrium in relation to the sickling gene in the study environment.

The prevalence rates of hemoglobin variants AA $(71.5 \%)$ and AS (25.3\%) in this study is not in agreement with the findings by Jeremiah. ${ }^{13}$ This corroborates the fact that inherited hemoglobin variants vary significantly in various populations and ethnic groups around the world. The $71.5 \%$ prevalence of AA is within the normal range of $55 \%-75 \%$ earlier reported for Blacks. ${ }^{15}$ While the prevalence of AS in this study $(25.3 \%)$ is within the reference value of $20 \%-30 \%$

Table 4 Frequency distribution of the babies studied according to age group

\begin{tabular}{ll}
\hline Age group & Frequency, $\mathbf{n}(\%)$ \\
\hline $8-10$ months & $94(30.1 \%)$ \\
$11-13$ months & $144(46.2 \%)$ \\
$\mid 4-16$ months & $74(23.7 \%)$ \\
Total & $312(100 \%)$ \\
\hline
\end{tabular}

Table 5 Frequency distribution of the babies' HIV status according to age group

\begin{tabular}{llll}
\hline Age group & \multicolumn{2}{l}{ HIV status, $\mathbf{n}(\%)$} & Total \\
\cline { 2 - 3 } & Positive & Negative & \\
\hline $8-10$ months & I5 (I6\%) & $79(84 \%)$ & 94 \\
II-I3 months & $32(22.2 \%)$ & 1 I $2(77.8 \%)$ & 144 \\
I4-16 months & $17(23 \%)$ & $57(77 \%)$ & 74 \\
Total & 64 & 248 & 312 \\
\hline
\end{tabular}

Notes: $\chi^{2}=1.729 ; d f=2 ; P=0.440$.

Abbreviation: HIV, human immunodeficiency virus.

quoted for Nigeria and the $20 \%-40 \%$ in Africa in general. ${ }^{15-17}$ Abnormal hemoglobin SC genotype was the least prevalent in this study $(1.0 \%)$, but it is similar to the $2.0 \%$ reported by Egesie et al. ${ }^{18}$

When the null hypothesis - which states that babies' hemoglobin genotypes has no influence on babies' HIV status - was tested, it revealed a statistically significant influence on the babies who were HIV seropositive $\left(\chi^{2}=8.432, d f=3, P=0.034\right)$. The infants with SC genotype (66.7\%) demonstrated a relationship with HIV seropositivity. The reason for abnormal hemoglobin genotypes influencing babies' HIV seropositivity is not clear. This finding has not been previously documented among Nigerian babies and it was not previously reported or cited in the literature searched. Because the sample size is relatively small, it is recommended that more studies are needed with larger sample sizes to confirm this finding.

Blood group O $(43.3 \%)$ was the most frequently encountered phenotype and its predominance over other $\mathrm{ABO}$ blood groups in this study is in agreement with several previous reports from different parts of Nigeria..$^{7,13,14,18,19}$ An exception to this is the Gwari tribe of Abuja and the Rubuka tribe of Plateau State, Nigeria, where group B was reported to show predominance over the other blood groups. ${ }^{20}$ However, the frequencies of blood group $\mathrm{O}$ in the previous studies differ. The $43.3 \%$ prevalence of blood group $\mathrm{O}$ in this study is lower than the $54.2 \%$ reported among healthy infants population

Table 6 Frequency distribution of hemoglobin genotype of the HIV-exposed babies delivered by the pregnant women positive for HIV infection

\begin{tabular}{ll}
\hline Hemoglobin genotype & Frequency, $\mathbf{n}(\%)$ \\
\hline AA & $223(71.5 \%)$ \\
AC & $7(2.2 \%)$ \\
AS & $79(25.3 \%)$ \\
SC & $3(1 \%)$ \\
Total & $312(100 \%)$ \\
\hline
\end{tabular}

Abbreviation: HIV, human immunodeficiency virus. 
Table 7 Cross tabulation analysis of baby's hemoglobin genotype versus HIV status

\begin{tabular}{llll}
\hline $\begin{array}{llll}\text { Hemoglobin } \\
\text { genotype }\end{array}$ & \multicolumn{2}{l}{ HIV status, $\mathbf{n}(\%)$} & Total \\
\cline { 2 - 3 } & Positive & Negative & \\
\hline AA & $39(17.5 \%)$ & $184(82.5 \%)$ & 223 \\
AC & $3(42.9 \%)$ & $4(57.1 \%)$ & 7 \\
AS & $20(25.3 \%)$ & $59(74.7 \%)$ & 79 \\
SC & $2(66.7 \%)$ & $1(33.3 \%)$ & 3 \\
Total & 64 & 248 & 312 \\
\hline
\end{tabular}

Notes: $\chi^{2}=8.432 ; d f=3 ; P=0.034$.

Abbreviation: HIV, human immunodeficiency virus.

in Ibadan, South Western Nigeria. ${ }^{21}$ The high frequency of group $\mathrm{O}$ in this population provides an advantage in terms of availability of blood for blood transfusion especially in emergencies. However, some level of caution has to be exercised since some group $\mathrm{O}$ blood is known to contain potent immune hemolytic antibodies (hemolysins).

The $36.8 \%$ prevalence of blood group A in this present study is not in accordance with the $21.6 \%$ reported among healthy infant population in Ibadan, Nigeria. ${ }^{21}$ It is also higher than some previous reports from other parts of Nigeria. ${ }^{7,13,14}$

The $15.7 \%$ frequency of blood group B in this study is lower than the $21.4 \%$ reported among healthy infants population in Ibadan, Nigeria, ${ }^{21}$ but is in proximity to the reported frequency of $17.1 \%$ for group B in Port Harcourt, Nigeria. ${ }^{13}$ Blood group $\mathrm{AB}$ was the least prevalent (4.2\%) in this study and this is in accordance with all previous reports. However, this rate is higher than the $2.8 \%$ reported among healthy infants in Ibadan, Nigeria ${ }^{21}$ and the $2.97 \%$ reported among individuals in Benin City, Nigeria. ${ }^{7}$ It is in proximity to the reported frequency of $4.0 \%$ for group $\mathrm{AB}$ among American Blacks $^{22}$ and the $4.84 \%$ in Port Harcourt, Nigeria. ${ }^{13}$

The current study found the frequency of $\mathrm{RhD}^{-}$ phenotype to be $4.4 \%$ and $\mathrm{RhD}^{+}$phenotype to be $95.6 \%$. This is in agreement with Omotade et al. ${ }^{21}$ The $4.4 \%$ rate of $\mathrm{RhD}^{-}$in this study is, however, higher than some previous reports. ${ }^{23,24}$

In this current study, no $\mathrm{AB}^{-}$baby was encountered $(0 \%)$. The reason for this is not clear, probably because both blood group $\mathrm{AB}$ and $\mathrm{RhD}^{-}$individuals are very rare in Nigeria. The absence of blood group $\mathrm{AB}^{-}$among the study population indicates a higher percentage of protection against the $\mathrm{Rh}$ alloimmunization problem and low incidence of incompatibility and hemolytic disease of the newborn. The findings have clearly demonstrated the existence of genetic variability and polymorphism in regards to $\mathrm{ABO}$ and $\mathrm{Rh}$ blood groups among the population sampled.
Babies HIV seropositive status was not found to be associated with the babies' blood groups as was expected (Fisher's exact test $=9.140, P=0.169$ ). . However, blood group $\mathrm{AB}^{+}$shows the highest rate of HIV-1 seropositivity (46.2\%), followed by $\mathrm{A}^{+}(23.9 \%)$. This is in contrast to the report by Abdulazeez et al, ${ }^{11}$ in which they reported blood group $\mathrm{AB}$ to be with the highest rate of HIV-2 infection. Because the sample size is relatively small, more studies are needed with larger sample sizes to confirm these findings.

\section{Conclusion}

This study has revealed an association between abnormal hemoglobin SC and HIV-1 infection and not with ABO and Rh blood groups among HIV-exposed infants in North Western Nigeria. Further studies with larger sample sizes are recommended to confirm these findings.

\section{Disclosure}

The authors report no conflicts of interest in this work.

\section{References}

1. Weatherall D. The inherited disorders of haemoglobin: an increasing neglected global health burden. Indian J Med Res. 2011;134(4): 493-497.

2. World Health Organization. Sickle-Cell Anaemia. In: Fifty-Ninth World Health Assembly; May 22-27, 2006; Geneva, Switzerland.

3. Akigbe RE, Ige SF, Afolabi AO, Azeez OM, Adegunlola GJ, Bamidele JO. Prevalence of haemoglobin variants, ABO, and Rhesus blood groups in Ladoke Akintola University of Technology, Ogbomosho, Nigeria. Trends in Medical Research. 2009;4(2):24-29.

4. Patel J, Patel A, Patel J, Kaur A, Patel V. Prevalence of haemoglobinopathies in Gujarat, India: a cross-sectional study. Internet J Hematol. 2008;5:1.

5. Reid ME, Lomas-Francis C, Olsson ML. The Blood Group Antigen Facts Book. 3rd ed. New York, NY: Academic Press; 2012:1-760.

6. International Society of Blood Transfusion. Table of blood group systems. Oct 2008. Available from: http://ibgrl.blood.co.uk/isbt.

7. Enosolease ME, Bazuaye GN. Distribution of ABO and Rh-D blood groups in the Benin area of Niger-Delta: implication for regional blood transfusion. Asian J Transfus Sci. 2008;2(1):3-5.

8. Pennap GR, Ekeleme IK, Igbawua I. Frequency distribution of haemoglobin genotype, $\mathrm{ABO}$ and Rhesus blood groups among a cohort of pregnant women in northern Nigeria. Research Opinions in Animal and Veterinary Science. 2011;Suppl 1:S1-S4.

9. Lee HH, Wu HY, Chuang YC, et al. Epidemiologic characteristics and multiple risk factors of stomach cancer in Taiwan. Anticancer Res. 1990;10(4):875-881.

10. Edgren G, Hjalgrim H, Rostgaard K, et al. Risk of gastric cancer and peptic ulcers in relation to $\mathrm{ABO}$ blood type: a cohort study. Am J Epidemiol. 2010;172(11):1280-1285.

11. Abdulazeez AA, Alo EB, Rebecca SN. Carriage rate of human immunodeficiency virus (HIV) infection among different ABO and Rhesus blood groups in Adamawa State, Nigeria. Biomed Res. 2008;19(1):41-44

12. Moormann AM, Embury PE, Opondo J, et al. Frequencies of sickle cell trait and glucose-6-phosphate dehydrogenase deficiency differ in highland and nearby lowland malaria-endemic area of Kenya. Trans R Soc Trop Med Hyg. 2003;97(5):513-514. 
13. Jeremiah ZA. Abnormal haemoglobin variants, ABO and Rh blood groups among student of African descent in Port Harcourt, Nigeria. Afr Health Sci. 2006;6(3):177-181.

14. Bakare AA, Azeez MA, Agbolade JO. Gene frequencies of ABO and Rhesus blood groups and haemoglobin variants in Ogbomoso, South-West Nigeria. Afr J Biotechnol. 2006;5(3):224-229.

15. Fleming AF, Lehman H. Sickle Cell Disease: A Handbook For General Clinician. Edinburgh: Churchill Livingstone; 1982.

16. Reid HL, Famodu AA. Spectrophotometric quantification of haemoglobin S fraction in heterozygous sickle-cell trait (HbAS). Med Lab Sci. 1988;45(2):143-145.

17. Sinou MT. Antenatal screening of sickle cell disease. [webpage on the Internet]. Geneva: Geneva Foundation for Medical Education and Research; 2003 [updated August 17, 2012]. Available from: http://www. gfmer.ch/Endo/PGC_network/antenatal_screening_sickle_cell_Tchana. htm. Accessed May 18, 2014.

18. Egesie UG, Egesie OJ, Usar I, Johnbull TO. Distribution of ABO, Rhesus blood and haemoglobin electrophoresis among the undergraduate students of Niger Delta University, Nigeria. Niger $J$ Physiol Sci. 2008;23(1-2):5-8.
19. Worlledge S, Ogiemudia SE, Thomas CO, Ikoku BN, Luzzatto L. Blood group antigens and antibodies in Nigeria. Ann Trop Med Parasitol. 1974;68(3):249-264.

20. Onwukeme KE. Blood group distribution in blood donors in a Nigerian population. J Physiol Sci. 1990;6(1):67-70.

21. Omotade OO, Adeyemo AA, Kayode CM, Falade SL, Ikpeme S. Gene frequencies of $\mathrm{ABO}$ and $\mathrm{Rh}$ (D) blood group alleles in a healthy infant population in Ibadan, Nigeria. West Afr J Med. 1999;18(4): 294-297.

22. Conteras M, Lubenko S. Immunohaematology: introduction. In: Hoffbrand AV, Lewis SM, Tuddenhan EGD, editors. Postgraduate Haematology. 4th ed. London: Arnold Publishers; 2001:164-181.

23. Ahmad SG, Obi SO. The incidence of ABO and Rhesus D blood groups in Northern Nigeria. Niger J Med. 1998;7:68-70.

24. Ahmed SG, Umar BA, Saidu AT, Jolayemi B. Pattern and clinical significance of $\mathrm{ABO}$ and Rhesus-D red cell phenotypes among blood donors in Birnin Kudu, Nigeria. Borno Medical Journal. 2004;1:1-6.
Pathology and Laboratory Medicine International

\section{Publish your work in this journal}

Pathology and Laboratory Medicine International is a peer-reviewed, open access journal focusing on innovative basic research and translational research related to pathology or human disease. The journal includes original research, updates, case reports, reviews and commentaries on current controversies. The Academic Sponsor

\section{Dovepress}

of this journal is the Chinese American Pathology Association (CAPA). The manuscript management system is completely online and includes a very quick and fair peer-review system. Visit http://www.dovepress.com/testimonials.php to read real quotes from published authors.

Submit your manuscript here: http://www.dovepress.com/pathology-and-laboratory-medicine-international-journal 